quirements, was supplied by 58 generating stations. Of these stations, 27 small ones supplied only four per cent of the total load, the average generating cost per unit being more than $\mathbf{1} \cdot \mathbf{5} d$. Five groups of large stations supplied 66 per cent of the total load, the average generating costs being $0 \cdot \mathbf{4} 66 d$. per unit. When the extensions at Barking and the new stations at Battersea and Fulham come into operation, even better results will be obtained by the larger stations. The fundamental geographical feature from the point of view of electrical generation is the Thames Valley, with its abundant supply of water for condensation purposes and its facilities for the transport of waterborne coal. In a lecture by J. D. Peattie, published in the Electrician for May 6, an account is given of the interconnexion of the generating stations in the London area. Within a radius of ten miles from Charing Cross, there are now hundreds of lattice towers supporting stranded cables for the grid at 132 kilovolts and for connecting stations at 66 and $33 \mathrm{kv}$. There is a notable river crossing between Barking and Northfleet, where two towers, 487 feet high, will give a clearance under the wires at high water of $250 \mathrm{ft}$. on a span of $3060 \mathrm{ft}$. These towers are the highest on the grid and will carry two double circuits. They are specially painted, and will be illuminated at night to give warning to aircraft flying along the Thames Valley. On the way to Southend one of them is now a conspicuous landmark.

\section{The Hannah Dairy Research Institute}

A BRIEF account of the researches already carried out at the recently established Hannah Dairy Research Institute, Kirkhill, Ayr, is given by the director, Dr. N. C. Wright, in the Ayrshire Cattle Society's Journal, vol. 3, No. 1. An investigation into the incidence of certain bovine diseases, especially tuberculosis and milk fever, has been commenced, and, as a result, recommendations have been made which should lead to the elimination from tested herds of a large proportion of the animals reacting positively to the tuberculin test. Inquiry is also being made into the length of life of milking cows in Scottish herds and into the main causes which lead to the unremunerative disposal of stock. The problems of the utilisation of surplus milk and of milk by-products also received attention. Investigations on the biological side require laboratory accommodation, which has only recently become adequate with the completion of the buildings at Kirkhill. They will include a re-investigation of the protein requirements of dairy cows, and an investigation of the physiology of lactation. In addition, the problems involved in improvement of the dairy stock by selective inbreeding and in the methods used in condensing and drying milk, sepa. rated milk, and whey will be examined. Two-thirds of the income of the Institute is received in the form of a grant from the Development Commissioners, but the remaining third must be raised from non-government sources. It is estimated that $£ 2000$ will be required annually, and it is hoped to secure an endowment fund which will supply an assured income of this order.

No. 3265, VoL. 129]

\section{Anthropological Bibliography}

ANTHROPOLOGY in particular among the sciences is not well served in the matter of indices and bibliographies, though what is needed is, perhaps, co-operation rather than extended effort. There is already in existence a number of bibliographies dealing each with some one or more departments of anthropological science. Some of these overlap, and none can be called really complete. The latest of these has been compiled by M. Joseph Nippgen, librarian of the Société de Géographie of Paris, and has appeared in L'Ethnographie ; it may be obtained separately from the Société d'Ethnographie de Paris. It covers contributions to general and comparative ethnology, and folklore and comparative religion, while ethnographical papers and books dealing with specific geographical areas are grouped under continents. A few items in archæology and physical anthropology are included. This bibliography has the additional advantage that a considerable number of the items are analysed at some length by the compiler. There is, unfortunately, no indication of the period of publication covered by the compilation as a whole, though the latest date appearing is 1929 . The current issue of L'Anthropologie (T. 40, Nos. 5-6) is devoted entirely to an index of vol. 21-40 of that periodical, issued for the years 1910-31. The index is divided into two parts, of which the first contains a list of authors in alphabetical order and the second is a subject index. Titles of original communications and variétés are distinguished from book reviews by a difference in type; but no distinction is made between the names of authors of books reviewed and of original communications. In consequence, the arrangement gives undue prominence to what, from the point of view of most who will wish to consult L'Anthropologie, must be regarded as much in the nature of second-class matter. Notwithstanding this inconvenience, the index is a great boon, and an example that might well be followed with advantage by many more of the British scientific periodicals which have a long run.

\section{New Mayan Site in Yucatan}

A RUINED Mayan city of enormous proportions, previously unknown, has been discovered in southern Yucatan by Mr. C. L. Lundell, a representative of the American Chicle Development Company. The ruins are situated in the south-east corner of Campeche and are difficult of access ; but under an arrangement with the Mexican Government they have been inspected by Dr. Sylvanus G. Morley, accompanied by a party of five. The city has been named Calakmul, "The Two Adjacent Hills", by its discoverer. In Dr. Morley's report, as circulated by Science Service, of Washington, D.C., the site is said to contain many more sculptured monuments than any Mayan city hitherto known. There are no less than one hundred and three stelæ with sculptured figures and hieroglyphs. Some of the stelæ are of high artistic merit. Fifty-one are dated, and one-half of these have been deciphered. It is evident that the city was once a 